Digital Press Social Sciences and Humanities

On the Pursue of World Heritage Status: Conservation vs Tourism

Dwirahmi Suryandari

Proceeding of Indonesia Heritage Tourism Forum 2019 (IHTF2019)

Dewi Pratika Ayu Dhira Pradati (eds) 


\title{
On the Pursue of World Heritage Status: Conservation vs Tourism
}

\author{
Dwirahmi Suryandari* \\ Badan Pengelola Kawasan Kota lama Semarang, Semarang, Indonesia \\ *e-mail: anastasia.dwirahmi@gmail.com
}

\begin{abstract}
In the past few years, UNESCO World Heritage status has become more popular in Indonesia. Many cities are trying to get their sites inscribed on this prestigious list. This ambition has made some city governments take major efforts in revitalizing their heritage sites. Semarang with its famous Old Town -formerly a trading hub during the Dutch colonial period, is jumping on the bandwagon. UNESCO World Heritage is based on the 1972 Convention which accompanied by its operational guidelines. This convention set the standards on what kind of site could be listed as a world heritage and how a state party should manage and nominate their property accordingly. Critics have argued that the standards are Eurocentric, both in terms of the site selection and the management. In a developing country like Indonesia, heritage preservation has its own discourse. People were skeptical about the benefit of preserving heritage mainly because it seemed to only entertain the needs of the elites, professionals, and academics. That is why the approach towards heritage preservation in a city like Semarang has shifted to become more populist, which apparently has its backlash. The approach strives to preserve heritage sites and buildings while at the same time provide social and economic advantages for the community through tourism. However, this approach has turned heritage conservation into careless beautification projects that might have gone too far from UNESCO standards for world heritage. This paper will answer why it seems unrealistic to pursue this title considering the ongoing social and economic issues. It will also tell what heritage preservation practice and policy are lacking thus making the site management failed to meet the standards of the 1972 Convention. In a broader sense, this paper will examine what are the odds and challenges for developing countries in nominating their sites as World Heritage, especially in the era of mass tourism.
\end{abstract}

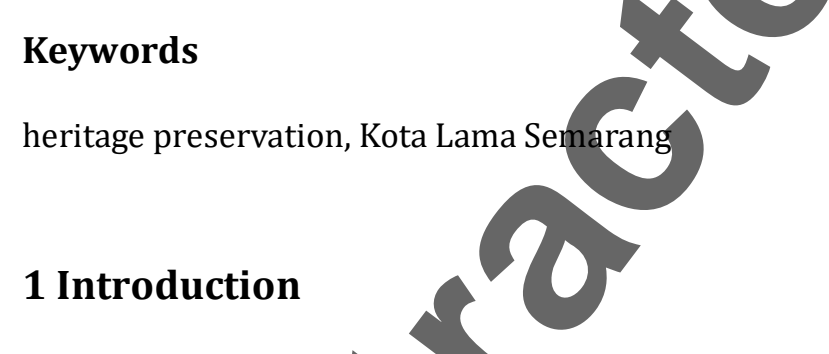

While the idea of tourism and heritage seems to be inseparable and compatible with one another, the reality has proven otherwise. Already in 2011, the World Heritage Committee reported that out of 39 properties in the Asia Pacific that were monitored, 26\% were endangered by tourism. In 2012, four sites in the Asia Pacific region were listed as World Heritage Sites in Danger -including the Tropical Rainforest of Sumatra in Indonesia- and tourism was one of the reasons for which these sites were inscribed in the list (UNESCO, 2012). There are many more current examples of how tourism ruined well-known World Heritage Sites, such as the infamous cases of Angkor, Machu Picchu, and Luang Prabang. Recent incidents with the cruise ship in Venice also sparked outrage among heritage professionals and this issue remains unresolved even after the World Heritage Committee meeting in Baku last July 2019.

In a country so rich in natural and cultural assets like Indonesia, tourism grows fast and in a competitive manner between local governments. Each one of them is trying their best to promote their own tourist attractions to boost income from this particular sector. The city government of Semarang for example claimed that they managed to generate tax as much as Rp. 246,8 billion from the tourism industry in the year 2018. The strategy then moves forward into making Semarang more acknowledged both at the national and international levels. That is why the city government is pursuing the title of UNESCO World Heritage Site mainly for Kota Lama Semarang (Old City). Several measures that have been done in recent years include the renovation of historic buildings, improvement of public facilities and infrastructure, and the promotion of public-private partnerships for heritage building management and maintenance. The 
government had also drafted a management plan that is set for the year 2019 - 2024 and a management board called BPK2L (Badan Pengelola Kawasan Kota Lama - Old Town Management Board) has been established even since 2007.

In most cases, the inscription as a World Heritage will indeed lead to an increased number of visitors to the site. Ironically, this expectation to use world heritage status as bait for tourists is against the initial purpose of the world heritage convention itself, which aimed for revitalizing heritage for the education and future generations. Therefore, a more careful treatment should be applied for a site aspire to be a world heritage site in order to avoid the downside of tourism practices.

\section{Semarang as a world heritage city}

The campaign to set forth Kota Lama as a World Heritage Site actually started around 2012. This movement was led by heritage activists and professionals in order to raise the awareness of heritage conservation among younger generations. The government welcomed this initiative and arranged the strategy to put Semarang in the list for the year 2020 and as of early 2015, it is already on the tentative list. Kota Lama is arguably the best feature of urban heritage in Semarang, the capital city of Central Java. This historic area is comparable to, if not more impressive than the one in Jakarta (known as Kota Tua), and has received much international attention, mainly from the Dutch government and organizations. Many believe that if the conservation and management plans for Kota Lama work well, this historic city will be equal to George Town in Malaysia, or Vigan in the Philippines-both are World Heritage Sites.

To be inscribed in this prestigious list, a site must have an Outstanding Universal Value (OUV) and meet at least one of the ten criteria. To begin with, a country must prepare a nomination file. The file consists of a nomination dossier and other accompanying documents such as the management plan -including tourism development strategy, assessment reports, and map of the site and its buffer zones. The government of Semarang has decided that Kota Lama will be nominated for its relevance in the sugar industry and trading during the 19th and 20th centuries. In March 2018, the government of Semarang through The Agency of Spatial Planning launched a project worth as much as $\$ 49,800$ for the drafting of World Heritage nomination dossier.

\subsection{A brief history of the old Dutch quarter}

The historical value of Kota Lama is mainly based on its former function as the main trading hub on the north coast of Java during the Dutch East Indies period. During that time, the rivalry between small kingdoms in Java brought a big advantage for the Dutch. In 1677, under the rule of Cornelis Speelman, the VOC was able to control the north coast of Java as a tribute from the Mataram Kingdom. Kota Lama reflects the significance of Semarang from the 16th until the early 20th century. It is acclaimed for its intactness and authenticity in comparison to many other historical districts across Indonesia.

The existence of this historic city is believed to have played a major role in international trade and migration-which later affected the social and political situation in the city. Kota Lama Semarang consists of colonial-style buildings that served as the administrative center for trading during the Dutch colonial period in the 19th-20th century. The Dutch built this industrial town close enough to the port in order to secure and control their business in the middle part of Java. In this town, some of the buildings included churches, warehouses, offices, and a train station. This town-planning concept was very much influenced by the industrial revolution happening in Europe at that time. Modern enterprises replaced many traditionallocal companies. The VOC and also many of the Chinese ruled the trading activities across Java, thus making the locals become their mere laborers. During those periods, Semarang came into its own as one of Indonesia's metropolitan centers.

Adding more to those historical significances of the city, Semarang is famously known as the city where the history of the railway system in Indonesia began. In the early 20th century, when the explosion of sugar trade happened, the Dutch began to build railways that connected Semarang as a port city to the hinterlands where the sugar cane plantations were located. This event signed a crucial moment in Indonesia's industrial and transportation history. The railway system also secures Semarang as one of the most important cities in the Dutch East Indies.

This glorious era of Kota Lama lasted until the Japanese overruled the Dutch colonial government and took over many strategic assets all over Indonesia. Many warehouses in Kota Lama were turned into military stations and Dutch companies abandoned their offices. After independence, Kota Lama remained 
dormant, dark, and shabby for a long period of time, causing squatters, criminals, and prostitutes to move into its streets and empty buildings. Documentations on what was happening to Kota Lama throughout those times are rarely found; the prominent Indonesian architectural historian Johannes Widodo referred to this 1960 s-1990s period in the district's history as "a black hole". Nowadays, Kota Lama Semarang is still considered to be one of the main business districts in Semarang. It is the district where some major stateowned enterprises operate, primarily those that were nationalized from the Dutch after independence.

\subsection{Conservation projects and problems}

Conservation work in Kota Lama after Indonesia's independence was first recorded in the year 1980. A project was initiated by YAKOMA, an abbreviation for Yayasan Kota Lama (Kota LamaFoundation), that was focused on the beautification of the street by fixing pavements and installing street lamps. The projects in these early years of conservation were mostly initiated by academics from universities. The effort to revitalize the area continues slowly and didn't get many acknowledgments. In 2003, the city government issued a local regulation (Peraturan Daerah No. 8 Tahun 2003) on the management of Kota Lama as a heritage site.

The grand design for the conservation of Kota Lama Semarang as a heritage site was actually been published in 2011. This document was issued by the Agency of Regional Development Semarang as a result of a year-long consultation with heritage experts from in and outside the city. However, this 200-page document is hard to be implemented since it is entirely filled with the research's findings rather than direct recommendations for the site's management. Although these documents consider Kota Lama to have the potential to attract tourists, none of them has included an assessment of the impact of tourism.

Besides the physical conservation plans and projects in Kota Lama, many activities are also initiated by local communities and organizations. This new wave of heritage activism began in 2010 with the help of social media and mostly initiated by university students and artists. Some of these initiatives, even though might be unintentional, have contributed to increasing the number of visitors to Kota Lama.

In the beginning, it seems that the city government's policies and projects failed to accommodate the interest of local residents in Kota Lama mainly because all of those initiatives did not involve the community in the process. Later on, the government started to realize that community involvement is indeed become one of the most important aspects according to UNESCO. Therefore, the policymakers started to think about some ways in which the people in Kota Lama could be involved in these revitalization projects. However, it seems that the strategy to include the community in this process is solely by giving them a chance to generate income for economic advantage through the tourism sector rather than really involve them in the discussions about the strategy itself. While it seems that tourism could benefit the community's welfare, it doesn't mean that everybody in Kota Lama is interested in that particular sector. Mainly those people who don't even run a business, to begin with.

Even for those who run businesses in Kota Lama, the beautification projects by the government doesn't always bring them advantages. Phase one of infrastructure development involving the ministry of public works that was conducted in 2018 - 2019 has caused many debates amongst the people in Kota Lama. Some of them feel that the construction disturbed their daily business and activities by blocking the roads, causing air pollution, and sanitation problems. Many of the restaurant owners also feel uneasy about the new policy of restricting cars and motorcycle to be parked right in front of their shops for there are some newly designated parking spots around Kota Lama. The centralized parking system in a public open space is not common in Indonesia and seems unpractical for some people.

Some residents also act indifferently towards this revitalization effort. This attitude is related to the lack of sense of belonging of the community towards the history of the site, as much as the government wants them to do so. Of course, they value the fact that it is their homes, but not necessarily that they have to preserve it particularly when preserving will cost them more fortune rather than generate income for them. Kota Lama is not a living heritage, for the community, losing the authenticity of it doesn't mean losing their identity.

The city government tends to promote heritage conservation as a tool to gain economic advantage for the people of Kota Lama and also for Semarang as a whole. The most important purpose of conservation according to UNESCO which is education, is hardly ever mentioned. Many revitalized buildings are functioned for cafes, restaurants, souvenir markets, and shops because these kinds of businesses generate income faster and bigger. Despite its rich and vibrant history, not a single museum has been established in Kota Lama. The site is also lack of interpretation tools such as a brochure, map, and signage. Visitors who come to Kota Lama are only entertained by the façade of the buildings without knowing the history or the 
value of the site itself. It is expected that the government starts to design education-based tourism to foster a more sustainable approach for Kota Lama revitalization.

\section{Challenging the purpose of heritage conservation}

There have been many examples of how a World Heritage Site status is used to boost the economy of a city and generate income for the community. This applies mainly to urban heritage since it is situated in a dynamic setting of a modern city. In a developing country, many urban poor settle within these heritage buildings. Therefore, it is not surprising that when the government tries to conserve urban heritage, they also have to think about the strategies to engage the people and how to gain their support.Urban heritage conservation in Indonesia also faces this challenge. According to the national law on cultural heritage (Law on Cultural Conservation, 2010), people's welfare becomes one of the purposes of heritage conservation. It means that every conservation measure should weigh on its ability to serve the community's benefit. In short, conservation should not only be done for the sake of the property or attribute but also the people living amongst them.

Smith (2006) argued that tourism and particularly mass tourism happened as a consequence of what she refers to as Authorized Heritage Discourse (AHD). AHD is basically a reinforcement of "common identity" through the concept of heritage, where a leader, politician, or elite define the meaning of heritage and which of this heritage should be taken care of by the current generations to be passed on to the future generations. This idea usually focuses on the aesthetic aspect of heritage. Further, Smith (2012) suggests that AHD consider heritage not as the actual past, but rather a construction of the past to serve current agendas. AHD treats heritage as a mere passive object thus making it a consumable material instead of a dynamic one that allows further interpretation.

Contestation of who has the right to heritage also was also pointed out by Herzfeld (2010) where he mentioned how confrontation could happen when government and private enterprises treat conservation for purely economic benefit. This kind of treatment that occurs in many urban heritage sites across Asian Countries has led to gentrification and commodification of private spaces. Even an already designated World Heritage Site such as George Town experience the downside of its prestigious title. An online article from Barron (2017) said that even though UNESCO has saved many of the jetties from destruction, it has also brought commercialization into the area. Kota Lama is no exception to this. In a recent interview, the residents revealed how the sudden construction projects in Kota Lama disturbed their daily activities. Even some business owners experience loss of income due to roadblocks and unhealthy air that made customers reluctant to visit their shops.

There have been so many critics towards the decision of the government to prioritize the revitalization only for the Old Town. Kota Lama is arguably the most aesthetically pleasing part of Semarang's urban heritage. Most of the buildings are still intact. That's why the priority is not given to other quarters such as the Malay, Chinese, and Javanese settlements. These three sites, even though as rich in history as Kota Lama, have deteriorated or changed a lot because of development, neglect, and land subsidence. Therefore, Kota Lama is regarded to be the 'readiest' and 'easiest' to manage since most of the buildings are still relatively intact.

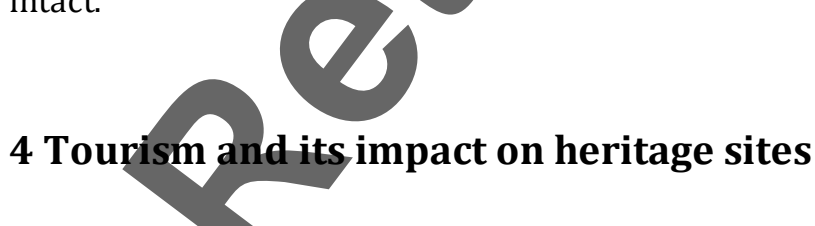

Tourism is a fast-growing industry in Indonesia. World Travel and Tourism Council announced that Indonesia tourism grows by 7,8\%, double the global average of 3,9 (World Travel and Tourism Council, 2018). The tourism sector also contributes a significant amount for national income, sitting at number four after CPO, oil and gas, and coal. However, the tourism ministry admitted that as of the end of 2018, Indonesia has only reached 10 million out of the targeted 17 million foreign tourists. It means that in the years to come, the ministry will push the regional government to develop, maintain, and promote their assets to increase visitation numbers.

Inscribing properties as a World Heritage will bring benefits such as; a better presentation of properties, bring honor and prestige for the city, trigger the community's appreciation of their heritage, stronger protection for the property, and lastly boost activities related to tourism (UNESCO, 2012). In the year 2011, UNESCO launched a manual book called Managing Tourism at World Heritage Sites: a Practical Manual for 
World Heritage Site Managers. This manual shows UNESCO's point of view of tourism in heritage sites. It is highly recommended that tourism activity in a World Heritage site should not ruin the value of the site or damage the attributes of the property. It is also important that tourism strategy is developed based on the criteria for which a property is inscribed. Furthermore, this document suggests the importance of involving the local community in the process.

There are many examples where tourism could damage a heritage site, including in Indonesia. Borobudur was once considered to be included in the list of world heritage in danger because the visitor number surpasses its carrying capacity. There was no appropriate or adequate measure to protect the site from tourism activity. However, this largest Buddhist temple in the world now has better visitor management and also a proper site interpretation. However, an interesting case comes from Luang Prabang. Despite many heritage experts' concern the rapid changes that happened in this Laos historical city, local managers argued that the changing of traditional houses happened to serve the need for tourism business and that as Staiff and Bushell stated is an "eastern approach to change, which is different to a western approach of conservation (Caust \& Vecco, 2017, p. 9). This argument shows that in developing countries conservation efforts should adjust to conditions that might not be present in more developed countries such as in Europe.

\section{Finding the middle ground}

Already on the first page of the document "Preparing World Heritage Nominations" (UNESCO, 2011), it is mentioned that economic advantage should not be the sole purpose of nominating a property as a World Heritage. Referring to UNESCO's 1972 convention on which the World Heritage List is based, the purpose of the world heritage system is to identify and further protect heritage sites around the world to maintain their Outstanding Universal Value (OUV). However, it seems that the listing of a site comes in one package with increased popularity for tourism. Since this case is inevitable, site managers and the government should establish a policy that will both ensure the protection of the property and at the same time serve the tourism industry. Some measures that could be developed are creating a better community involvement method, integrating heritage conservation and sustainable tourism policies, and also design education- and experience-based tourism.

On the 30th anniversary of the 1972 convention, World Heritage Committee issued the Budapest Declaration that listed the objectives to support World Heritage called the 4C's: the credibility of the World Heritage List, conservation of World Heritage Properties, capacity-building measures, and increase public awareness through communication. The fifth $C$ was later added in 2007 which says: to enhance the role of communities in the implementation of the World Heritage Convention. The additional objective clearly takes side with the people and promote a more engaging approach of (world) heritage preservation projects. Referring to the 5C's objectives will at least show how the government is committed to following the UNESCO standards and values which will increase the likeability to become a World Heritage Site.

Community or residents of Kota Lama should be involved in the development plan not only as mere objects but also as actors who could actively participate in the decision-making process related to tourism. Community engagement tools include various instruments that advise, mobilize, and engage local communities. These tools are essential to extract or generate knowledge and skills that already exist within the community and to avoid gentrification. These knowledge from the people are essential to attract visitors considering that tourist nowadays wants more genuine stories and real experiences.

Regarding the potential to have a more sustainable approach for heritage tourism, Nasser argues that

Sustainable tourism is rooted in sustainable development, in the sense that if tourism is to contribute to sustainable development, it must be economically viable, environmentally sensitive, and culturally appropriate (Nasser, 2003, p. 474).

As mentioned earlier, tourism in heritage sites should not cause degradation to the value and the physical condition of the attributes. Therefore a good tourism management plan should pay attention to activities that might threaten the integrity and authenticity of the site. One example of sustainable tourism activity is through volunteer-tourism. Semarang City Government can adapt the UNESCO's World Heritage Volunteer Program and invite young people to volunteer at Kota Lama Semarang for an amateur conservation works or participate in developing the digital marketing strategy for the site. It will also answer the current trend of tourist preference to have a more engaging experience during their visit. 
Lastly, a good interpretation tool should be designed and established in Kota Lama for example a city or site-specific museums, signage, and temporary exhibition. Proper research and community participation are needed to produce an engaging story for the site. With these strategies, we would find a middle ground between heritage conservation and tourism which makes a World Heritage Status more feasible to obtain.

\section{References}

Barron, L. (2017). 'Unesco-cide': does world heritage status do cities more harm than good? Retrieved August 30, 2017, from The Guardian website: https://www.theguardian.com/cities/2017/aug/30/unescocide-worldheritage-status-hurt-help-tourism

Caust, J., \& Vecco, M. (2017). Is UNESCO World Heritage recognition a blessing or burden? Evidence from developing Asian countries. Journal of Cultural Heritage, 27, 1-9. https://doi.org/10.1016/j.culher.2017.02.004

Herzfeld, M. (2010). Engagement, Gentrification, and the Neoliberal Hijacking of History. Current Anthropology, 51(S2), S259-S267. https://doi.org/10.1086/653420

Law on Cultural Conservation. , Law of the Republic of Indonesia § (2010)

Nasser, N. (2003). Planning for Urban Heritage Places: Reconciling Conservation, Tourism, and Sustainable Development. Journal of Planning Literature, 17(4), 467-489. https://doi.org/https://doi.org/10.1177

Smith, L. (2006). The Uses of World Heritage. New York: Routledge.

Smith, Laurajane. (2012). A Pilgrimage of Masculinity. The Stockman's Hall of Fame and Outback Heritage Centre. Australian Historical Studies, 43(3), 472 482. https://doi.org/10.1080/1031461X.2012.708116

UNESCO. (2011). Preparing World Heritage Nominations. In Heritage.

UNESCO. (2012). Understanding World Heritage in Asia and the Pacific: The Second Cycle of Periodic Reporting 2010-2012. World Heritage Paper. Retrieved from https://unesdoc.unesco.org/ark:/48223/pf0000218275

World Travel and Tourism Council. (2018). Indonesia Travel and Tourism Growing Twice as Fast as Global Average. Retrieved (from https://www.wttc.org/about/media-centre/press-releases/pressreleases/2019/indonesian-travel-and-tourism-growing-twice-as-fast-as-global-average/ 